\title{
Public Interest to Personal Data: Online Databases of Russian Archives
}

\author{
Elena ROMANOVA, PH.D. \\ Deputy Director, The All-Russian Scientific and Research Institute for Records and Archives Management (VNII- \\ $D A D), 82$ Profsoyuznaya street, Moscow 117393 Russia \\ e-mail: romanova@vniidad.ru
}

Public Interest to Personal Data: Online Databases of Russian Archives

\begin{abstract}
The article describes the difficult choice between public and personal interests which the archivists have to make while providing access to archival documents with personal information. A special attention is given to creation of databases, which facilitate the search for information, but being accessible to the unlimited number of users may cause distress or damage to the data subject or to his/her relatives. By the example of the united open access data bank "Memorial" of the Russian Ministry of defense, it is demonstrated how different the conception of data protection law and archival legislation can be, depending on the circumstances. The imperfection of the legislation which creates many problems for archives gives them at the same time more possibilities for the realization of their social, cultural and educational functions.
\end{abstract}

Key words: access to archives, archives of the Ministry of defense of Russia, data protection, OBD "Memorial", online databases of archives, personal data, victims of World War II

Interesse pubblico nei dati personali: database online degli archivi russi

\section{SINTESI}

L'articolo descrive la difficile scelta tra interessi pubblici e personali che gli archivisti devono fare fornendo accesso ai documenti d'archivio con informazioni personali. Un'attenzione particolare è riservata alla creazione di database, che facilitano la ricerca di informazioni, ma essere accessibili ad un numero illimitato di utenti può causare danni alla persona interessata o ai suoi parenti. Con l'esempio della banca dati ad accesso libero "Memoriale" aperta del Ministero della Difesa russo, è dimostrato quanto sia diversa la concezione della legge sulla protezione dei dati e la legislazione archivistica, a seconda delle circostanze. L'imperfezione della legislazione che crea molti problemi per gli archivi offre loro allo stesso tempo maggiori possibilità per la realizzazione delle loro funzioni sociali, culturali ed educative.

Parole chiave: accesso agli archivi, archivi del Ministero della Difesa russo, protezione dei dati, banca dati ad accesso libero "Memoriale", database archivistici online, dati personali, vittime della Seconda guerra mondiale

Javni interes do zasebnih podatkov: spletne podatkovne baze ruskih arhivov

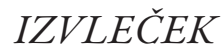

$\mathrm{V}$ članku je opisana težka izbira med javnimi in individualnimi interesi, ki jo morajo arhivisti opraviti in hkrati omogočati dostop do arhivskih dokumentov z osebnimi podatki. Posebna pozornost je namenjena ustvarjanju podatkovnih zbirk, ki olajšajo iskanje informacij. Dostop je omogočen neomejenemu številu uporabnikov, kar lahko povzroči stisko oziroma škodo posamezniku ali njegovim sorodnikom, na katerega se podatki nanašajo. $\mathrm{Na}$ primeru združene podatkovne banke "Memorial" ruskega ministrstva za obrambo, je razvidno, kako je zasnova zakona o varstvu podatkov oziroma arhivska zakonodaja lahko različno konceptirana, odvisno od okoliščin. Nepopolnost zakonodaje, ki povzroča veliko težav arhivom, jim hkrati daje več možnosti za uresničevanje njihovih socialnih, kulturnih in izobraževalnih funkcij.

Ključne besede: dostop do arhivov, arhivi Ministrstva za obrambo Rusije, varstvo podatkov, OBD "Memorial”, spletne zbirke arhivov, osebni podatki, žrtve druge svetovne vojne 
Общественный интерес к персональной информации: базы данных российских архивов онлайн

\section{АННОТАЦИЯ}

В статье описывается непростой выбор между общественными и частными интересами, с которым повсеместно сталкиваются архивисты при организации доступа к архивным документам, содержащим персональную информацию. Особое внимание уделяется вопросу создания баз данных, которые упрощают поиск информации, но будучи доступными неограниченному числу пользователей, могут причинять ущерб субъекту данных или его родственникам. На примере объединенного банка данных «Мемориал» Российского Министерства обороны, демонстрируется, каким разным может быть понимание действующего законодательства в сфере защиты персональных данных и архивного дела в зависимости от обстоятельств. Несовершенство законодательства, которое создает много проблем архивам, в то же время предоставляет им больше возможностей Аля реализации их социальной, культурной и образовательной функций.

\section{The right to privacy in Russian legislation}

Nowadays, in the modern Russia, the right to privacy (private life) is recognized as one of the fundamental human rights. At the international level, it is acknowledged in the UN Universal Declaration of Human Rights, the European Convention on Human Rights, the International Covenant on Civil and Political Rights, and many other international agreements. The Constitution of the Russian Federation guarantees that everyone in the state has the right to inviolability of private life, personal or family secrets, protection of honor and dignity (Konstitutsia..., 1993, art.23).

The Russian Federal Law on Personal Data, implemented on July 27, 2006 (last redaction was carried out on December, 31, 2017), constitutes the backbone of Russian privacy laws and requires data operators to take all the necessary legal, organizational and technical measures required for protecting personal data against unlawful or accidental access. (Federal'ny zakon... No. 152-FZ of July 27, 2006, art.19, paragraph 1).

\section{Regulation of personal data processing in archives}

Archives of all types deal with personal data and may be regarded as data operators. According to the law, a personal data operator is a state body, municipal body, legal entity or an individual that organizes and/or effects processing of personal data and also determines the goals and content of personal data processing. (Federal'ny zakon... No. 152-FZ of July 27, 2006, art.3, paragraph 2).

But for the archives the problem of due processing of personal data is much wider than for any other institution. They deal not only with the data of archive's users or their own employees. Rather often, archival documents contain personal information, sensitive data as well. Archival fonds and collections can hold personal and family secrets, sometimes unknown even to the living members of the family. In great measure this refers to Russian archives, for example, to the former Communist party archives, archives of security or military services of the Soviet Union.

According to the article 1 of the Russian Federal Law on Personal Data, this law does not apply to processing of personal data already presented in archival fonds. ((Federal'ny zakon... No. 152-FZ of July 27, 2006, art.1, paragraph 2). While dealing with archival documents selected for permanent preservation for public benefit, archives are guided by the Federal Law of October 22, 2004 No. 125-FZ "About archiving in the Russian Federation" (Federal'ny zakon... No. 125-FZ of October 22, 2004).

According to the Law, the access to archival documents containing information about personal or family secrets of a citizen, his/her private life, or information which constitutes a menace to his/her safety is limited for the period of 75 years from the creation of these documents (Federal'ny zakon... No. 125FZ of October 22, 2004, art.25, paragraph 3).

\section{Personal and family secrets: what kind of data is involved?}

As it is seen from this statement, not all the types of personal data are protected by the archival law, and there are many possibilities for different interpretations of its statements. Certainly, a wide range of 
other legislative acts, regulations, directives, etc. must be taken into account, including the mentioned law on personal data, the civil code, labour code, family code, tax code, code of criminal procedure, laws on the national census, on rehabilitation of victims of political repressions, on fundamentals of protection of health of citizens in the Russian Federation, etc. (see Khimina et al., 2015). "Personal and family secrets" are understood as the data about adoption, about the private life of the spouses, personal property and non-property relations in the family and other. But there is no exhaustive list of data which can be referred to personal and family secrets. Theoretically, these are all the types of data which a data subject wishes to be kept in secret from the others.

The difference between personal secrets and family secrets is that the first concern only the interests of a particular individual, while the second concern the interests of several persons which have relations regulated by the Family code of the Russian Federation. The legislation doesn't give the answer how to reconcile a dispute if there are different opinions of the members of one family concerning their common secrets.

\section{Provision of access to archival documents: balancing between public and personal interests}

The inexactitude of the legislation creates many problems for archives, but also gives them more freedom in provision of access to archival information. In Russia nowadays, one of the main tasks of state public archives and archives of ministries is to make documents, which were closed for decennaries, accessible to users, to help people in their search for information about their relatives, to give the society representation about the part of the history of the state, which was hidden from its citizens for a certain period of time.

The process of declassification, as the part of this activity, has become a stable and systematic work, which is being performed by archivists together with other state structures concerned.

As for provision of access to archival documents containing personal or family secrets of the years passed by, the reasonable balance between public and personal interests is obviously indispensable. The problem is that often it's rather difficult to find an equilibrium. All the criteria are rather approximate and cannot be considered as absolute. "Public interest" can change over time and circumstance and therefore cannot be clearly defined. Personal opinion of archivists influences a lot the definite decision, as well as the current tendencies in the archival sphere and in the society.

In many cases the archivists can only assume that this or that personal information could cause distress or damage to the data subject or to his/her relatives, and therefore, they can put the limitations to access to archival documents. They can judge also, guided by their own principles and common sense, that this or that data is not sensitive anymore and can be publically accessible. Evidently, the facts which could be estimated as harmful some decennaries ago, in the modern society are accepted much less emotionally. This gives more opportunities to archives to create databases, to make expositions and publications of archival documents, and to provide access to their resources online.

Otherwise, imperfection of legislation may also be the reason of eventual distress or damage to the data subject. It is recognized by many archivists that the 75-year period of limitation of access to archival documents containing personal information is not always sufficient to protect interests, inward peace and dignity of the data subject or other persons concerned (see Romanova, 2016). For example, the fact of adoption of a child learned by him being at the age of 75 years may seriously influence his moral and physical health. As well as it can be rather harmful to learn the fact that your father-in-law, which you were very close with, was the author of the anonymous report to the authorities about the imaginary high treason of your biological father in the 30-es. Nevertheless, the Russian legislation does not permit the prolongation of the period of limited access, regardless of whether the data subject is alive or not.

The circumstances accompanying the fact of getting the information about your family may also influence a lot your perception of the family secret. Evidently, if you got data while consulting archival documents in the reading room of archives, it is less harmful than if you learned it from the popular book printed in a big number of copies or from the open-access Internet resources. 


\section{Archival resources in the digital environment: risks and benefits}

The digital environment is advantageous and perilous at the same time because it facilitates the spread, search and use of information.

Archives as institutions dealing mostly with processing of information are active users of the advantages of digital era. The digitization of archival documents is one of the main activities of archives nowadays. Another effective way to make archival documents more accessible to the general public is creating electronic finding aids, preferably in the form of different databases, and presenting them online.

Obviously, when dealing with personal information consideration should be given to how regulation of the access to digital copies will be realized, what information can be presented in online catalogues and databases, and so on. Both the public interest and the respect to the privacy of individuals must be taken into account. Archivists have to be sure that processing of personal data is legal, subject to safeguards. Sometimes an online presentation of archival resources containing some personal data may need authorization. In some cases provision of online access to archival databases and digital copies of archival documents or, on the contrary, limitations to the access may need special explaining to the public.

\section{Data bank "Memorial" of the Ministry of defense}

There were a lot of debates in the Russian society around the united open access data bank "Memorial" (hereinafter - OBD "Memorial"), founded upon the initiative of the Ministry of defense of the Russian Federation in 2007. (Internet 10).

It is a bank of personal information about the soldiers and officers killed in action, reported as dead or missing during the Great Patriotic War (1941-1945) and in the post-war period.

The search is performed through a catalogue by last name, first name, patronymic, year/date of birth, military rank. Alongside with the mentioned data, all the users of the database can find there the places of service, official causes and circumstances of death, and places of burial of the participants of this terrible war. The copies of confirming documents are also accessible at the website, as well as their reference codes are given.

First appeared in the open access, OBD "Memorial" got a broad positive response at the society. A lot of people received an opportunity to learn about the destiny of their relatives from the united resource, based on the documents not only from the Ministry of defense, but from other archives too. Some of these documents were declassified only at the course of realization of this project. The data bank also includes information received as a result of the activity of volunteer search groups.

That was the case when the social demand and public interests were determining factors for the creation and further development of an open-access archival resource based on personal information.

\section{Social reaction to the limitation of access to OBD "Memorial" in 2010}

In 2010, with the entering into force of the Law on personal data, a part of information regarded as sensitive was excluded from the open access Data bank. The copies of corresponding documents were also hidden from Internet users.

Thus, information about the destiny of soldiers and officers who, after capture, had gone over to the enemy, or had been shot by NKVD officers for the non-compliance with orders was changed to the neutral phrase "other cause of death or retirement".

The reason for this extraction was officially explained by the Ministry of defense, which considered that this type of information can be harmful for the living members of the family of the mentioned persons and therefore cannot be in the open access resources.

This position caused the burning indignation in the society, which estimated the correction of the data as an attempt of embellishment of the history.

After the campaign in the mass media (TV channel NTV) against the limitations of access to the part of information of OBD "Memorial" and the collective appeal to the President of the Russian Feder- 
ation signed by hundreds of people, the juridical expertise was organized and in three months all the limitations were concealed. (Internet 9).

\section{OBD "Memorial" in 2018}

The database continued to get updated every year. Only in 2015, 250 thousand documents were processed, the database was completed by 3 million of new names.

Nowadays OBD "Memorial” contains more than 17 million digital copies of lists of irrecoverable losses and 20 million names. Initial burial locations of 5 million soldiers and officers were revealed.

Thanks to the digitization of documents, the names of 1 million war prisoners of the fascist camps have already been restored. But, according to the German data, there were more than 5 million Soviet citizens in captivity. So the names and the destinies of more than 4 million prisoners are still unknown.

It is still necessary to find and process the lists and cards of wounds, the files from the sanitary units and medical battalions.

So the project is continuing to develop and it makes its contribution to the reconstruction of the history of the World War II and demonstrates how many human lives our victory cost. But its main goal is to help people to find information about their relatives who lost their lives at this war.

\section{The significance of the online project}

The social and international significance of the project is indisputable. But considering the certain sensitivity of personal data presented in the OBD "Memorial", the realization of the project was possible only because the archival legislation in Russia regarding personal data is rather flexible, and the public opinion is often much more powerful than an opinion of a single person. The fact that this project was initiated by the Ministry of defense is also very important.

It needs to be noted though, that during the years when the Data bank was on the web, nobody claimed that it caused some distress or damage to any individual. Otherwise, people expressed the opinion that they needed to know all the truth about their fathers and grandfathers - participants of the War, even if the circumstances of their death were not heroic.

Some archival documents used for the project are containing personal information about German soldiers, officers or non-military people. Russian archivists worked in collaboration with their German colleagues and the decision about the form of use of these documents was made in compliance with the requirements of the German legislation.

\section{Conclusion}

The World Wide Web has changed the way in which people communicate, spread and consume information; it has made data exchange much faster, but more vulnerable. This caused the necessity of better protection of personal data in the digital environment.

In Russia, the Federal Law on Personal Data (Federal'ny zakon... No. 152-FZ of July 27, 2006) is being constantly redacting. But the archives are guided not by this law, but by the archival legislation, which makes the archivists balance between public and individual interests while providing access to archival documents containing personal information.

The legislation is not concrete and comprehensive enough to give the definite answers to all the possible controversial questions in this regard. Together with the necessity of the awareness of the legislative requirements and professional recommendations (for example, Kurnikova, 2005, Khimina et al., 2015), archivists need to be well informed of the current processes in the society and its expectations, to exercise common sense, moral and ethical principles when providing access to archival resources based on personal information. The example of the Data bank "Memorial" of the Russian Ministry of defense demonstrates the difficulties which could be met by archives while creating, developing and moderating open-access databases, and realizing their activities in the public interest. 


\section{References}

\section{Books}

Kurnikova, I. (2005). Dostup k personal'nym dannym: zakonodatel'stvo i praktika (otechestvenny i zarubezhny opyt): Metodicheskoe posobie / Rosarhiv, VNIIDAD.

(Курникова И.А. (2005). Аоступ к персональным данным: законодательство и практика (отечественный и зарубежный опыт): Методическое пособие / Росархив, ВНИИААА).

Khimina, N. et al. (2015). Ispol'zovanie arhivnyh documentov soderzhaschih konfidentsial'nuyu informatsiyu ohranyaemuyu gosudarstvom (za isklyucheniem gosudarstvennoy tayny): Metodicheskie rekomendatsii. Dep. SIF OCNTI VNIIDAD N. 270.

(Химина Н.И. и Ар. (2015). Использование архивных документов, содержащих конфиденциальную информацию, охраняемую законодательством (за исключением государственной тайны): Методические рекомендации. Аеп. в СИФ ОЦНТИ ВНИИААА. ․ 270).

\section{Articles in journals}

Romanova, E. (2016) Regulation of access to personal data in the archives: issues, trends and challenges. In: $A T$ LANTI, 26 (1), pp. 109-115.

\section{Legal and other documents}

Code of Ethics for Archivists. Available at http://www.ica.org/sites/default/files/ICA_1996-09-06_code\%20 of\%20ethics_EN.pdf (accessed on 30.07.2018).

Convention for the Protection of Human Rights and Fundamental Freedoms, the (the European Convention on human rights). Opened for signature in Rome on 4 November 1950, came into force in 1953. Available at http:// www.echr.coe.int/Documents/Convention_ENG.pdf (accessed on 30.07.2018).

Konstitutsia Rossiyskoy Federatsii (enacted by the nation-wide voting on the December 12, 1993). In: Rossiyskaya gazeta. 1993. n. 237.

(Конституция Российской Федерации (Принята всенародным голосованием 12.12.1993) // Российская газета. 1993. No 237).

Federal'ny zakon No. 125-FZ of October 22, 2004 "Ob arhivnom dele v Rossiyskoy Federatsii. In: Sobranie zakonodatel'stva RF. 2004. N. 43. Article 4169.

(Федеральный закон от 22.10.2004 N. 125-Ф3 «Об архивном деле в Российской Федерации» // Собрание законодательства РФ. 2004. N. 43. Ст. 4169).

Federal'ny zakon No. 152-FZ of July 27, 2006 “O presonal'nyh dannyh. In: Sobranie zakonodatel'stva RF. 2006. No 31 (part I). Article 3451.

(Федеральный закон от 27 июмя 2006 г. N 152-Ф3 «О персональных данных» // Собрание законодательства РФ. 2006. No 31 (часть I). Ст. 3451).

\section{Electronic sources}

NTV broadcast "Segodnya" of February 9, 2010. Available at http://www.ntv.ru/novosti/185829/ (accessed on 30.07.2018).

United open access data bank "Memorial”. Available at https://obd-memorial.ru/html/ (accessed on 30.07.2018).

\section{SUMMARY}

Archives in Russia while processing personal data in archival fonds and collections are guided not by the Law on Personal Data, but by the Law on Archiving in the Russian Federation, which put the limitations to access to archival documents containing information about personal or family secrets of a citizen, his/her private life, or information which constitutes a menace to his/her safety during the 75-year period from the creation of these documents. Obviously, at the provision of access to archival documents the reasonable balance between public and personal interests is indispensable. The criteria given in the legislation are rather approximate, that is why the personal opinion of archivists is important, as well as the current tendencies in the archival sphere and in the society. Nowadays archives widely use the advantages of the digital environment. But this process needs to be taken under 
strict control. All the possible risks must be estimated when presenting online archival resources containing personal data. A lot of debates in the Russian society there were around the united open access data bank "Memorial", founded upon the initiative of the Ministry of defense of the Russian Federation in 2007. That was the case when the social demand and public interests were determining factors in the creation and further development of an open-access archival resource based on personal information.

Typology: 1.01 Original scientific article

Submission date: 03.08 .2018

Acceptance date: 08.08 .2018 